\title{
Inhibition Activity of Angiotensin Converting Enzyme (ACE) and Determination of Total Phenolic and Flavonoid Compound from Bitter Melon Leaves (Momordica charantia L.)
}

\author{
Putri Lestari, Katrin, Rissyelly*, Putu Gita Maya Widyaswari Mahayasih
}

Putri Lestari, Katrin, Rissyelly*, Putu G.M.W. Mahayasih

Department of PharmacognosyPhytochemistry, Faculty of Pharmacy, Kampus Baru UI Depok, Jawa Barat, 16424, INDONESIA.

Correspondence

Rissyelly

Department of Pharmacognosy-Phytochemistry, Faculty of Pharmacy, Kampus Baru UI Depok, Jawa Barat, 16424, INDONESIA.

Phone: +62 217270031

Email: rissyelly@yahoo.com

\section{History}

- Submission Date: 21-12-2016;

- Review completed: 05-01-2017;

- Accepted Date: 11-01-2017.

DOI : 10.5530pj.2017.2.43

Article Available online

http://www.phcogj.com/v9/i2

\section{Copyright}

(C) 2017 Phoog.Net. This is an openaccess article distributed under the terms of the Creative Commons Attribution 4.0 International license.

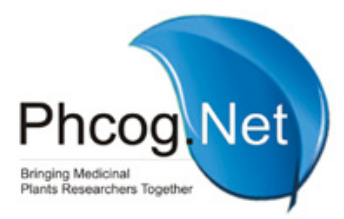

\begin{abstract}
Introduction: Hypertension is a leading problem in Indonesia, because of the high prevalence and the long term effect. Bitter melon leaves (Momordica charantia L.) has been traditionally utilized to treat hypertension, yet not many studies explained the antihypertension effect of this plant. Methods: This study was conducted to test the benefit of bitter melon leaves as antihypertension using angiotensin converting enzyme inhibition activity in $80 \%$ ethanolic extract and its fractions (n-hexane, ethyl acetate, and n-butanol) using ACE kit-WST (Dojindo, Japan). Then the antihypertension activity was associated with the phenolic content which was expressed in gallic acid equivalent (GAE) and total flavonoid in quercetin equivalent (QE). Results: Result of the study showed that the IC50 value obtained from the ethanolic extract to inhibit ACE activity was $7.52 \mu \mathrm{g} / \mathrm{mL}$ and the highest inhibition obtained in ethyl acetate fraction with IC50 value was $4,29 \mu \mathrm{g} / \mathrm{mL}$. Phenolic total and flavonoid total determination also showed that the highest content obtained in ethyl acetate fraction with $18.752 \mathrm{mg}$ GAE/gr extract and $8.310 \mathrm{mg} \mathrm{OE} / \mathrm{gr}$ extract, respectively. Conclusion: According to the study, it could be concluded that bitter melon (Momordica charantia L.) leaves provide inhibition activity against Angiotensin Converting Enzyme (ACE) and chemical compounds that were expected to play an active role in inhibiting ACE were flavonoid and tannin.
\end{abstract}

Key words: Momordica charantia L., Antihypertension, Angiotensin converting enzyme, Total phenolic, Total flavonoid.

\section{INTRODUCTION}

Indonesia is a tropical country with a high potential for providing medicinal plants. From 30,000 plant species live in Indonesia, 9,600 species had been studied as medicinal plants and around 300 species had been utilized in traditional medicine by traditional medicine developer. A plant in Indonesia which has potential as a medicinal plant is bitter melon ( $\mathrm{Mo}$ mordica charantia L.). Bitter melon leaves contain alkaloid, tannin, saponin, flavonoid and heart glycoside. ${ }^{1}$ Flavonoid is a chemical compound which showed more than hundreds types of bioactivity. Some flavonoids roles are accelerated blood flow in the body, antioxidant function, contain anti-inflammation effect, and reduce pain. In the previous study, showed that the majority plants contain high flavonoid content could play a role as an effective ACE inhibitor in vitro and in vivo. ${ }^{2}$ Other study showed that the bioactive polysaccharide isolated from bitter melon (Momordica charantia L.) provided Angiotensin Converting Enzyme Inhibition activity with $94.1 \%{ }^{3}$

Hypertension or the increased blood pressure was a global health problem which was a risk factor for heart disease, stroke, kidney failure, premature death, and disability. Each year around 9.4 million deaths recorded caused by hypertension in the world. ${ }^{4}$ In Indonesia the prevalence of hypertension obtained from blood pressure measurement in $\geq 18$-year-old population was $25.8 \%$, the highest was found in Bangka Belitung (30.9\%), followed by South Kalimantan (30.8\%), East Kalimantan (29.6\%) and West Java (29.4\%).

According to the argument above, this study was conducted to define the Angiotensin Converting Enzyme (ACE) Inhibition Activity from bitter melon (Momordica charantia L.) leaves. The Angiotensin Converting Enzyme (ACE) inhibition activity was tested in $80 \%$ ethanolic extract and its fractions (nhexane, ethyl acetate, and n-butanol) of bitter melon leaves. Then the determination of total phenolic and total flavonoid content from the bitter melon ( $\mathrm{Mo}$ mordica charantia L.) leaves fractions.

\section{MATERIALS AND METHODS}

\section{Materials}

Analytical balance, digital balance (ACIS, Japan), oven vacuum (Hotpack, England), pH meter (Eutech Instruments, France), maceration containers, condenser, Buchner filter, freezer in $-20^{\circ} \mathrm{C}$, refrigerator in $2-6^{\circ} \mathrm{C}$ ( $\mathrm{GEA}^{\circ}$, German), blender, thermometer, vortex mixer (VM-2000, Taiwan), orbital shaker incubator in $37^{\circ} \mathrm{C}$ (Lan-line, Australia), rotary vacuum evaporator (IKA, India), water bath (Imperial', Australia), spectrophotometry UV-Vis, microplate reader, microplate, separation funnel, volume pipette, mi- 
cropipette 100-1000 $\mu \mathrm{L}$ (Eppendorf, German) and 10-100 $\mu \mathrm{L}$ (Thermo, China), and other glass instruments.

Study materials used in this study were bitter melon leaves (Momordica charantia L.) which were obtained from Balitro, Bogor, West Java. This plant had been determined in Plant Conservation Center of Science Agencies of Indonesia, Bogor, West Java, Indonesia. ACE (Angiotensin Converting Enzyme) kit (Dojindo, Japan), Captopril (Kimia Farma, Indonesia), ascorbic acid, quercetin, gallic acid, ethanol 96\% (Brataco, Indonesia), demineralized water (Brataco, Indonesia), ethyl acetate (Merck, German), n-hexane (Brataco, Indonesia), n-butanol (Brataco, Indonesia), methanol p.a (Brataco, Indonesia), ethanol p.a (Brataco, Indonesia), boric acid (Merck, German), sodium chloride (Merck, German), dimethyl sulphoxide (DMSO) (Merck), sodium acetate, 2,4,6-tripyridyls-triazine (TPTZ) (Sigma-Aldrich), iron (III) chloride (Merck), chloride acid (Merck), potassium chloride (Merck), sodium hydroxide (Mallinckrodt), aluminum chloride, acetate acid glacial, and distilled water (Faculty of Pharmacy of UI, Indonesia).

\section{Preparation of Sample}

ACE inhibition activity test was conducted using ACE kit-WST (Dojindo, Japan). This kit contains a substrate buffer, enzyme A, enzyme B, enzyme $\mathrm{C}$, indicator solutions, and coenzyme. The test procedure was based on the ACE inhibition test using kit-WST which had been conducted in the previous study. ${ }^{5}$ ACE inhibition activity was tested by pipetting 20 $\mu \mathrm{L}$ sample solutions to the hollows, then adding $20 \mu \mathrm{L}$ substrate buffers. Next, we added $20 \mu \mathrm{L}$ enzyme solutions. Then the mixtures were incubated at $37^{\circ} \mathrm{C}$ for 1 hour. After incubation, we added $200 \mu \mathrm{L}$ indicator solutions into the hollows and incubated at the room temperature for 10 minutes. After that, the absorption was analyzed using microplate reader at $450 \mathrm{~nm}$ as the wavelength. For blank solution 1, sample solution replaced with $20 \mu \mathrm{L}$ demineralized water. For blank solution 2, sample solution and enzyme solution were replaced with $40 \mu \mathrm{L}$ demineralized water. The standard solutions were tested by replacing sample solutions with captopril solutions.

Total phenolic content was measured using Folin-Ciocalteau method. ${ }^{6}$ The total phenolic content was expressed as Gallic Acid Equivalent (GAE) obtained from a gallic acid calibration curve. The main solutions $5000 \mathrm{ppm}$ was made by weighing $50 \mathrm{mg}$ sample and dissolved them in methanol p.a in $10 \mathrm{~mL}$ volumetric flasks and diluted to get $1000 \mathrm{ppm}$ solutions. The $200 \mu \mathrm{L}$ sample solutions then pipetted and inserted into the test tubes, $1.5 \mathrm{~mL}$ Folin-Ciocalteu reagent was added to the test tubes. Then the test tubes were incubated in a dark room and at the room temperature for 5 minutes. After 5 minutes, into each test tubes, we added $1.5 \mathrm{~mL} \mathrm{Na}_{2} \mathrm{CO}_{3} 6 \%$ and incubated again for 105 minutes in the dark room and in the room temperature. After incubated we conducted gallic acid absorption measurement using spectrophotometry UV-Vis at 740 nm wavelength.

Flavonoid was measured using modified aluminum chloride colorimetry method which was expressed as Quercetin Equivalent (QE) obtained from quercetin calibration curve. ${ }^{7,8}$ The 5000 ppm main solution was made by dissolving $50 \mathrm{mg}$ sample into methanol p.a. Then $0.5 \mathrm{~mL}$ was pipetted and $1.5 \mathrm{~mL}$ methanol, $0.1 \mathrm{~mL}$ aluminum chloride $10 \%, 0.1 \mathrm{~mL}$ sodium acetate $1 \mathrm{M}$, and $2.8 \mathrm{~mL}$ distilled water added. The solutions were incubated at room temperature for 30 minutes. The absorption was measured using spectrophotometry UV-Vis at $434 \mathrm{~nm}$ wavelength.

\section{RESULTS AND DISCUSSIONS}

\section{Materials Preparation}

Plants used in this study was bitter melon or Momordica charantia L. leaves which were obtained from BALITRO, Bogor, West Java in dry sim- plicia. This plant was determined by Plant Conservation Center of Science Agency of Indonesia, Bogor Royal Garden. The dry simplicia was sorted to separate the simplicia from the dirt that may be involved in the drying process so that we obtained a clean simplicia. Then the sorted simplicia was mashed using a blender to minimize the simplicia size. The aim of these steps was to widen the simplicia area, therefore, the extraction process could be optimized. Simplicia powder was then kept in a shady area and protected from the sun exposure to prevent damage and reduced quality.

\section{Simplicia Extraction}

Simplicia was extracted using maceration method. Maceration is a cold extraction method, which is by soaking simplicia in an appropriate solvent and for certain time. Maceration method was chosen because this method is simple and easy to do. Beside that the extraction process of the maceration method also can protect thermolabile compounds so that will not damage compounds contained in the plant.

The solvent used for the extraction process was ethanol $80 \%$. Ethanol can easily penetrate the cell membrane to draw the intracellular compounds. Besides that ethanol also an efficient solvent in cell wall degradation and draw the polyphenol compounds. ${ }^{9}$ By using ethanol $80 \%$ as the solvent, it is expected that the more polar or semipolar compounds can be drawn in the extraction process. In this maceration process, we conducted seven times solvent replacements so that we obtained an almost clear macerate. Then all macerate obtained was evaporated using rotary vacuum evaporator and water bath so that we obtained a condensed extract. The bitter melon condensed extract obtained from extraction was 122.93 gram with $24.59 \%$ yield value.

\section{Fractionation of the Extract}

The extract was fractioned using liquid-liquid partition method with solvents that did not mix and had different polarity. This was conducted to separate compounds dissolved in the appropriate solvent based on the polarity properties. By using fractionation process, it was expected that we could obtain a more specific compounds from each solvent.

Partition was conducted in each solvent until we obtained an almost clear solvent, therefore each solvent could completely draw the compounds contain the extract according to the polarity properties. Ethanol extract obtained before was suspended in warm water. Then we used nhexane solvent which is nonpolar to draw nonpolar compounds from the extract. Fractionation using $\mathrm{n}$-hexane solvent was conducted in seven times repetitions. Then the partition was continued with ethyl acetate solvent which is semi-polar with 14 times and n-butanol solvent which is polar with five times repetitions. The final residue from the fractionation process was water fraction. The fractions obtained from n-hexane, ethyl acetate, and butanol was $1.49,19.37$, and 9.17 gram, respectively. The yield value for each fraction could be found in Table 1 .

\section{ACE Inhibition Activity Test}

ACE inhibition activity was tested in $80 \%$ ethanolic extract and n-hexane, ethyl acetate, and n-butanol fractions of bitter melon (Momordica charantia L.) leaves using ACE kit-WST (Dojindo, Japan). This kit was consists of a substrate buffer, enzyme A, enzyme B, enzyme C, indicator solutions, and coenzyme. The substrate solution was 3-HB-GGG (3-hydroxybutyrylglycyl-glycyl-glycine). Enzyme A, enzyme B, and enzyme C, respectively, were ACE (Angiotensin Converting Enzyme), aminoacylase, and 3-hydroxybutirate dehydrogenase. Coenzyme was consists of diaphorase and $\mathrm{NAD}^{+}$while the indicator solution was WST-1.

ACE inhibition activity was tested conventionally which had been widely used. The majority of this method was by using HHL (Hippuryl-histidine-leucine) with hippurate acid formation from ACE catalysis process 
against the substrate. The disadvantage of this method was hydrolyzed hippurate acid absorption could interfere the absorption results in 228 $\mathrm{nm}$ wavelength, however, the not hydrolyzed HHL also could provide a strong absorption at that wavelength. This will cause a disruption in ACE activity absorption so that the result was not specific. ${ }^{10}$ Therefore, ACE activity test method was conducted using the kit because this method was more sensitive, accurate, and fast compared with the conventional method. ${ }^{11}$ The main principle of ACE inhibition test using this method was measuring the absorption of $3 \mathrm{HB}$ (3-hydroxybutirate) which was formed from ACE catalysis process against the 3HB-GGG substrate with WST-1 formazan.

We first added DMSO (dimethyl sulfoxide) to the study sample to help the dissolution of the sample. However, DMSO and other organic solvent were not recommended in more than $1 \%$ because they could affect study results. Then the sample was diluted in borate buffer which contains 380 $\mathrm{mM} \mathrm{NaCl}$. This was because borate buffer was a stable buffer and ACE showed a higher activity than this buffer. ${ }^{10}$ The used instruments in this study were microplate reader in $37^{\circ} \mathrm{C}$ as the incubated temperature for 1 hour. Then continued with indicator solution addition and incubated for 10 minutes in $25^{\circ} \mathrm{C}$. Next, the sample was measured at $450 \mathrm{~nm}$ wavelength using microplate reader.

Study procedures were based on ACE inhibition test using ACE kit-WST which had been done in the previous study. ${ }^{5}$ The sample was tested to obtain ACE inhibition percentage from $80 \%$ ethanolic extract of bitter melon leaves and $\mathrm{IC}_{50}$ value determination. Results of the study showed that ACE inhibition percentage of the study sample was $93.66 \%$ in 100 $\mathrm{ppm}$. Then we conducted a test to determine the $\mathrm{IC}_{50}$ value of the sample in $100 \mathrm{ppm} ; 50 \mathrm{ppm} ; 25 \mathrm{ppm} ; 12.5 \mathrm{ppm}$; and $6.25 \mathrm{ppm}$. $\mathrm{IC}_{50}$ sample could be found in Table 2 .

$\mathrm{IC}_{50}$ values obtained from the $80 \%$ ethanolic extract of bitter melon leaves was $7.52 \mu \mathrm{g} / \mathrm{mL}$. Captopril also tested as ACE inhibition activity standard and the $\mathrm{IC}_{50}$ value was $5 \times 10^{-8} \mu \mathrm{g} / \mathrm{mL}$. This showed that this plant had a good potential as ACE inhibitor, even though still not good enough if compared with captopril. Then ACE inhibition activity was tested in n-hexane, ethyl acetate, and n-butanol fractions and the result was $65,63 \%, 82,89 \%$, and $75,50 \%$, respectively. The highest inhibition value obtained in ethyl acetate fraction with $\mathrm{IC}_{50}$ value was $4,29 \mu \mathrm{g} / \mathrm{mL}$. $\mathrm{IC}_{50}$ ethyl acetate could be found in Table 3 and Figure 1.

Chemical compounds that were expected to play an active role in inhibiting ACE were flavonoid and tannin. Previous studies showed that flavonoid could be an effective ACE inhibitor in vivo and in vitro. ${ }^{2}$ Liu, et al. (2003) also reported that tannin was a polyphenol derivate and known has the ability as ACE inhibitor. Inhibition mechanism from both compounds was similar, by forming a chelate complex on the $\mathrm{Zn}$ atom from ACE. ACE is a zinc metallopeptidase, this means $\mathrm{Zn}$ atom in the active site of catalytic was needed to create catalysis reaction, therefore the inhibition on $\mathrm{Zn}$ could cause inhibition activity in ACE. ${ }^{12}$

\section{Total Phenolic Content Measurement}

Total phenolic content obtained from Momordica charantia L. leaves fraction was measured using spectrophotometry with Folin-Ciocalteu (FC) reagent. This study was using gallic acid standard since it was a simple phenolic acid compound and hydroxybenzoate acid derivate. Besides that, gallic acid also used because it was stable and had high purity level. The phenolic content measurement was conducted based on the reduction ability of phenol and the standard used. The principle was a reduction from the phenolic compound of Folin-Ciocalteu reagent in the study materials and therefore creating a blue complex which could be read by the spectrophotometry as visible light. The measurement was conducted on n-hexane fraction, ethyl acetate fraction, and n-butanol fraction in $740 \mathrm{~nm}$ after incubated for 105 minutes. The total phenolic
Table 1: Fraction yield obtained from $80 \%$ ethanolic extract of bitter melon leaves

\begin{tabular}{cccc}
\hline Solvent & $\begin{array}{c}\text { Extract Weight } \\
\text { (gram) }\end{array}$ & $\begin{array}{c}\text { Fraction Weight } \\
\text { (gram) }\end{array}$ & Yield (\%) \\
\hline $\begin{array}{c}\text { n-hexan e Fraction } \\
\text { Ethyl Acetat e } \\
\text { Fraction }\end{array}$ & 50 & 1,49 & 2,98 \\
n-butanol Fraction & 50 & 18,37 & 36,74 \\
\hline
\end{tabular}

Table 2: ACE inhibition activity in $\mathbf{8 0} \%$ ethanolic extract of bitter melon leaves

\begin{tabular}{cccc}
\hline Sample & Concentration $(\mu \mathrm{g} / \mathrm{mL})$ & $\begin{array}{c}\text { Inhibition } \\
(\%)\end{array}$ & $\begin{array}{c}\mathrm{IC}_{50}(\mu \mathrm{g} / \\
\mathrm{mL})\end{array}$ \\
\hline Bitter Melon & 33,53 & 77,46 & \\
Leaves & 16,77 & 58,86 & \\
Extract & 8,38 & 52,47 & 7,52 \\
& 4,19 & 47,57 & \\
& 2,10 & 42,51 & \\
\hline
\end{tabular}

Table 3: ACE inhibition activity in ethyl acetate fraction of bitter melon leaves

\begin{tabular}{cccc}
\hline Sample & $\begin{array}{c}\text { Concentration }(\mu \mathrm{g} / \\
\mathrm{mL})\end{array}$ & $\begin{array}{c}\text { Inhibition } \\
(\%)\end{array}$ & $\mathrm{IC}_{50}(\mu \mathrm{g} / \mathrm{mL})$ \\
\hline 33,53 & 82,89 & \\
Ethyl Acetate & 16,77 & 66,39 & \\
Fraction & 8,38 & 57,79 & 4,29 \\
& 4,19 & 49,99 & \\
& 2,10 & 44,05 & \\
\hline
\end{tabular}

content was expressed as milligram of gallic acid equivalent (GAE) per one gram sample (mg GAE/gram sample). Standard Calibration Curve of Gallic Acid could be found in Figure 2. Total phenolic in the fractions obtained were ranged from 0.749 to $18.752 \mathrm{mg}$ GAE/g extract. Total Phenolic Content from Momordica charantia L. could be found in Table 4 .

\section{Total Flavonoid Content Measurement}

Flavonoid content from Momordica charantia L. leaves fractions was measured using spectrophotometry with aluminum chloride $\left(\mathrm{AlCl}_{3}\right)$ reagent. The principle of colorimetry method using aluminum chloride was $\mathrm{AlCl}_{3}$ could create a stable complex. $\mathrm{AlCl}_{3}$ could create an acid-resistant complex with keto groups in C4 and hydroxyl groups in C3 and $\mathrm{C} 5$ obtained from flavone and flavonol. And also could create a non-acid resistance with ortho hydroxyl groups in ring A and B of the flavonoid ${ }^{7}$. The total flavonoid content was usually using quercetin compounds as the standard. The $\mathrm{AlCl}_{3}$ addition in the measurement causing wavelength movement towards the visible area and causing a more yellow color, while the sodium acetate used to maintain the wavelength in the visible area.

Results of the total flavonoid content measurement were expressed as mg quercetin equivalent (QE) per one gram sample (mg GE/gram sample). The measurement was conducted on n-hexane fraction, ethyl acetate fraction, and n-butanol fraction in $343 \mathrm{~nm}$ wavelength after incubated for 30 minutes. Standard Calibration Curve of Quersetin could be found in Figure 3. The total flavonoid data was ranged from 0.233 to $8.310 \mathrm{mg}$ QE/g extract. Total flavonoid Content from Momordica charantia L. could be found in Table 5 . 


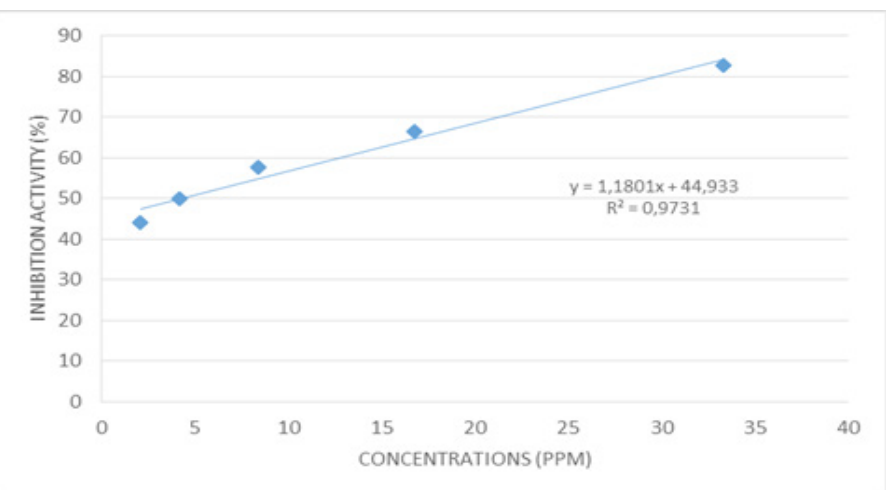

Figure 1: $I C_{50}$ Curve of Ethyl Acetate Fraction.

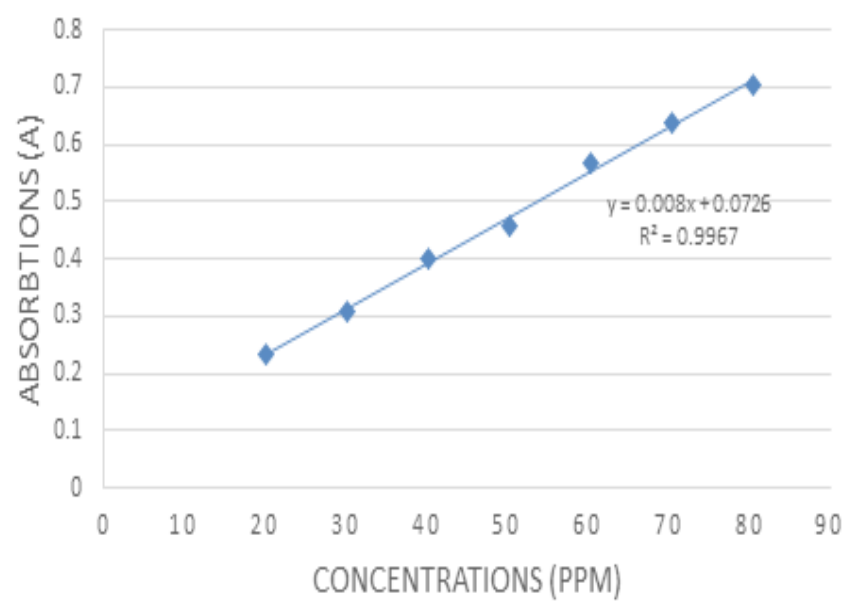

Figure 2: Standard Calibration Curve of Gallic Acid.

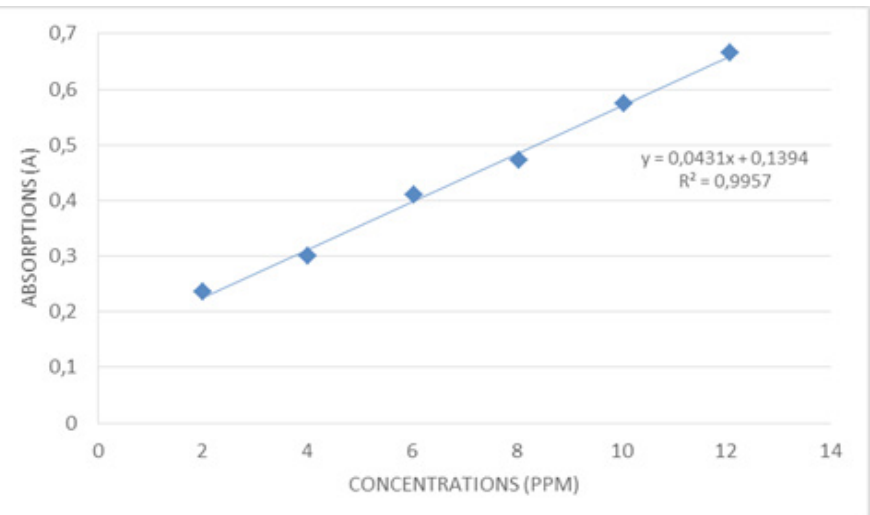

Figure 3: Standard Calibration Curve of Quercetin.

Table 4: Phenolic content data obtained from bitter melon (Momordica charantia L.) leaves

\begin{tabular}{ccc}
\hline Sample & $\begin{array}{c}\text { Sample concentrations } \\
(\mu \mathrm{g} / \mathrm{mL})\end{array}$ & Phenolic content \\
\hline mg GAE/g & & \\
n-hexane & 62,5 & $0,749 \pm 0,043$ \\
Ethyl acetate & 62,5 & $18,752 \pm 0,067$ \\
n-butanol & 62,5 & $5,796 \pm 0,036$ \\
\hline
\end{tabular}

Table 5: Flavonoid content data obtained from Momordica charantia L. leaves

\begin{tabular}{ccc}
\hline Sample & Sample concentrations $(\mu \mathrm{g} / \mathrm{mL})$ & $\begin{array}{c}\text { Flavonoid content } \\
\mathrm{mg} \mathrm{QE} / \mathrm{g}\end{array}$ \\
\hline n-hexane & 500 & $0,233 \pm 0,075$ \\
Ethyl acetate & 500 & $8,310 \pm 0,105$ \\
n-butanol & 500 & $3,402 \pm 0,476$ \\
\hline
\end{tabular}

\section{CONCLUSIONS}

According to the study, it could be concluded that $80 \%$ ethanolic extract of bitter melon (Momordica charantia L.) leaves provide inhibition activity against Angiotensin Converting Enzyme (ACE) with $\mathrm{IC}_{50}$ value was $7.52 \mu \mathrm{g} / \mathrm{mL}$. Ethyl acetate fraction from the $80 \%$ ethanolic extract of bitter melon (Momordica charantia L.) leaves showed the highest inhibition with $\mathrm{IC}_{50}$ value was $4,29 \mu \mathrm{g} / \mathrm{mL}$. Ethyl acetate fraction from the $80 \%$ ethanolic extract of bitter melon (Momordica charantia L.) leaves also showed the largest total phenolic content and total flavonoid content.

\section{ACKNOWLEDGMENT}

This study was supported financially by The Directorate of Research and Community Engagement, Universitas Indonesia via Hibah PITTA 2016.

\section{CONFLICT OF INTEREST}

All co-authors have seen and agree with the contents of the manuscript and there is no financial interest to report. We certify that the submission is original work and is not under review at any other publication.

\section{ABBREVIATIONS USED}

ACE: angiotensin converting enzyme; $\mathrm{IC}_{50}$ : inhibition concentration at $50 \%$; GAE: gallic acid equivalent; $\mathrm{QE}$ : quercetin equivalent.

\section{REFERENCES}

1. Mada S B, Garba A, Mohammed HA, Muhammad A, Olagunju A, Muhammad $A B$, Antimicrobial activity and phytochemical screening of aqueous and ethanol extracts of Momordica charantia L. leaves, Journal of Medicinal Plants Research. 2013:7(10):579-86.

2. Balasuriya $B N$, Rupasinghe $H V$, Antihypertensive properties of flavonoids-rich apple peel extract, Food Chemistry. 2012;135:2320-5. https://doi.org/10.1016/j. foodchem.2012.07.023 PMid:22980808.

3. Tan Hwee-Feng, Gan Chee-Yuen, Polysaccharide with antioxidant, $\alpha$-amylase inhibitory and ACE inhibitory activities from Momordica charantia, International Journal of Biological Macromolecules. 2016;85:487-96. https://doi.org/10.1016/j. ijbiomac.2016.01.023 PMid:26778156.

4. World Health Organization, A global brief on hypertension, 2013, Switzerland: WHO Press.

5. Bayarsaikhan D, YAMAKI K, Enkhtaivan G, Ichinkhorloo Z, Identification of angiotensin I-converting enzyme inhibitory activities from traditional Mongolian fermented milk products, Mongolian Journal of Chemistry. 2011;12(38):65-8.

6. Al-Saeedi $\mathrm{AH}$, Hossain M A, Evaluation of total phenols, total flavonoids and antioxidant activity of the leaves crude extracts of locally grown pigeon pea traditionally used in Sultanate of Oman for the treatment of jaundice and diabetes, Journal of Coastal Life Medicine. 2015;3(4):317-21.

7. Chang $\mathrm{C}$, Yang $\mathrm{M}$, Wen $\mathrm{H}$, Chern J, Estimation of total flavonoid content in propolis by two complementary colorimetric methods, Journal of Food Drug Analysis. 2002;10:178-82.

8. Pourmorad F, Hosseinimehr SJ, Shahabimajd N. Antioxidant activity, phenol and flavonoid contents of some selected Iranian medicinal plants, African Journal of Biotechnology. 2006;5(11):1142-5.

9. Tiwari P, Kumar B, Kaur M, Kaur G, Kaur H, Phytochemical screening and extrac tion: A Review, Internationale Pharmaceuticasciencia. 2011;1(1).

10. Lam LH, Shimamura T, Sakaguchi K, Noguchi K, Ishiyama M, Fujimura Y, et al, Assay of angiotensin I-converting enzyme-inhibiting activity based on the detection of 3-hydroxybutyric acid, Analytical Biochemistry. 2007;364:104-11. https://doi.org/10.1016/j.ab.2007.02.017 PMid:17386920. 
11. Lam LH, Shimamura T, Manabe S, Ishiyama M, Ukeda H, Assay of angiotensin Iconverting enzyme-inhibiting activity based on the detection of 3-hydroxybutyrate with water-soluble tetrazolium salt, Analytical Sciences. 2008;24:1057-60. https://doi.org/10.2116/analsci.24.1057.
12. Liu et al, Antihypertensive effects of tannins isolated from traditional Chinese herbs as non-specific inhibitors of angiotensin converting enzyme, Life Sciences. 2003;73(12):1543-55. https://doi.org/10.1016/S0024-3205(03)00481-8.

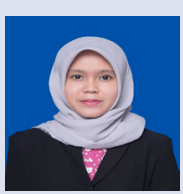

Putri Lestari: Finished her bachelor in pharmacy, at Faculty Pharmacy, Universitas Indonesia. Now she is an apothecary student in pharmacy, at Faculty Pharmacy, Universitas Indonesia.

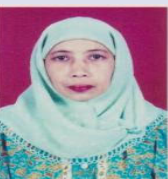

Katrin: finished her doctoral program in Biological Pharmacy, at Institut Teknologi Bandung. Her research in doctoral program was about Indonesia's traditional medicinal plants for immunostimulant analysis. She focused her research on phytochemicals field.

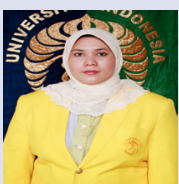

Rissyelly: finished her magsiter program in pharmacy, at Faculty Pharmacy, Universitas Indonesia. Her research in magister program was about antimalarial test of skin stem Calophyllum canum. currently, she is a doctoral student in pharmacy, at Institut Teknologi Bandung

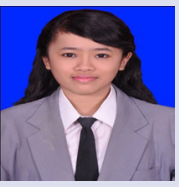

Putu Gita Maya W. Mahayasih: Finished her bachelor in pharmacy, at Faculty of Pharmacy, Universitas Jember. Now she is a master student at the Faculty of Pharmacy, Universitas Indonesia. Her master research focused on isolation of compound from Indonesia's medicinal plant.

Cite this Article: Lestari P, Katrin, Rissyelly, Mahayasih PGMW. Inhibition Activity of Angiotensin Converting Enzyme (ACE) and Determination of Total Phenolic and Flavonoid Compound from Bitter Melon Leaves (Momordica charantia L.). Pharmacogn J. 2017;9(2):252-6. 